\title{
Od Kompendium Katechizmu Kościoła katolickiego do YOUCAT. Uwagi o modelach pytań katechizmowych
}

\author{
From Compendium of the Catechism of the Catholic Church to YOUCAT. \\ Comments on catechism question models
}

\author{
Katarzyna Czarnecka \\ Wydział Filologii Polskiej i Klasycznej, \\ Uniwersytet im. Adama Mickiewicza w Poznaniu, ul. Fredry 10, \\ 61-701 Poznań, Polska; \\ e-mail: czar.ka@amu.edu.pl
}

\begin{abstract}
Abstrakt
Jednym z założeń, towarzyszących ogłoszonemu w 1992 roku Katechizmowi Kościoła katolickiego, jest powstanie opracowań doktrynalnych przeznaczonych dla zawężonego kręgu odbiorców. Przykładem publikacji o charakterze popularyzatorskim są m.in. Kompendium Katechizmu Kościoła katolickiego (wyd. 2005) oraz YOUCAT. Katechizm Kościoła katolickiego dla młodych (wyd. 2011, wierny przekład z języka niemieckiego). Pozycje te łączy powrót do tradycyjnej kompozycji katechizmowej, opartej na blokach składających się z pytania i odpowiedzi (z formy tej zrezygnowano w Katechizmie Kościoła katolickiego). Przedmiotem artykułu jest analiza pytań, zastosowanych na kartach YOUCAT, obejmująca 3 aspekty: (1) status pytań katechizmowych, (2) ich typologię oraz (3) wybrane cechy charakterystyczne, takie jak obecność presupozycji, zróżnicowanie relacji nadawczo-odbiorczych oraz niejednorodność stylistyczna. Autorka wysuwa wnioski dotyczące służebnej, dydaktycznej i perswazyjnej funkcji form dialogowych, kwalifikuje pytania katechizmowe jako pozorne i opisuje ich językową specyfikę, sprowadzającą się do korzystania z kilku schematycznych rozwiązań.
\end{abstract}

Słowa kluczowe: język religijny; katechizm; pytanie; popularyzacja.

\begin{abstract}
A common feature of the researched publications: Compendium of the Catechism of the Catholic Church (2005) and YOUCAT. Youth Catechism of the Catholic Church (2011), being a form of popularization of Catechism of the Catholic Church (1992), is a return to the traditional catechism composition based on blocks consisting of questions and answers. The purpose of the article is to analyze the questions used on YOUCAT pages. The analysis covers three aspects: 1. the status of catechism questions, 2. their typology, and 3. selected characteristics, such as the presence of presupposition, diversification of originator-recipient relations, and stylistic heterogeneity. The author draws conclusions regarding the servile, didactic and persuasive function of dialogue forms, qualifies catechism questions as only seeming questions and describes their linguistic specificity, boiling down to the use of several schematic solutions.
\end{abstract}

Keywords: religious language; catechism; question; popularization. 
Ogłoszony w 1992 roku, obowiązujący do dziś Katechizm Kościoła katolickiego ${ }^{1}$, opracowany w postaci obszernego wykładu, podzielonego na części, rozdziały i punkty, doczekał się w Polsce kilku analiz językoznawczych. Dotyczą one $z$ jednej strony unowocześnienia języka, $z$ drugiej - sygnalizują pewne trudności odbioru, wynikające tak ze struktury całego tekstu, budowy składniowej, jak i ze specyfiki leksykalnej ${ }^{2}$. Charakter i objętość monumentalnego opracowania stały się bodźcem do kolejnych przedsięwzięć $c^{3}$. Jednym z nich było zredagowane pod kierunkiem ówczesnego Prefekta Kongregacji Nauki Wiary, kardynała Józefa Ratzingera Kompendium Katechizmu Kościoła katolickiego (Kielce 2005) ${ }^{4}$, które ukazało się 13 lat później niż jego pierwowzór. Jak czytamy we Wprowadzeniu, „zawiera [Kompendium - K.Cz.] sformułowania bardziej syntetyczne tych samych treści" (Kompendium: 8), charakteryzuje się m.in. ścisłą zależnością od $\mathrm{Ka}$ techizmu Kościoła katolickiego, formą dialogową i użyciem obrazów w katechezie (Kompendium: 9) $)^{5}$. Istotną cechą Kompendium jest powrót do tradycyjnego, dialogowego modelu bloków pytanie - odpowiedź; Kompendium liczy ich 598 i obejmuje treści, które w Katechizmie ujęto w prawie 3000 punktów. Jak zaznacza kardynał J. Ratzinger, ,chodzi o zaproponowanie idealnego dialogu między nauczycielem i uczniem za pośrednictwem przynaglającej go sekwencji pytań, które wciągają czytelnika, zapraszając go do odkrywania ciągle nowych aspektów prawd swojej wiary" (Kompendium: 11).

Wśród kolejnych prób uprzystępnienia treści katechizmowych mieści się publikacja: YOUCAT polski. Katechizm Kościoła katolickiego dla młodych (Częstochowa 2011) ${ }^{6}$, wydana w związku z przygotowaniami do Światowych Dni Młodzieży w Madrycie w roku 2011, a będąca wiernym przekładem oryginału niemieckiego YOUCAT. Jugendkatechismus der Katholischen Kirche (Monachium 2011). Katechizm ten, opatrzony wstępem tego samego autora, co Kompendium, już papieża - Benedykta XVI, zrodził się z przekonania, że „tekst trzeba dopasować do potrzeb różnych środowisk, aby przemówić do poszczególnych

${ }^{1}$ Pierwsze wydanie po polsku: Katechizm Kościoła katolickiego, Poznań 1994. Założenia przyświecające opracowaniu wyraża fragment: „Wykład nauki powinien być jednocześnie biblijny i liturgiczny, przedstawiający zdrową doktrynę i dostosowany do życia współczesnych chrześcijan" - Jan Paweł II, Przemówienie na zakończenie Synodu nadzwyczajnego (7 grudnia 1985): AAS 78 (1986) 435, cyt. za: Jan Paweł II b.r.

2 O języku katechizmów - zob. np.: Bajerowa 1999; Bajerowa 2008; Bugajski 2008; Rybka, Sławek 2008.

${ }^{3}$ Kolejne opracowania są realizacją założeń, zapisanych w Konstytucji apostolskiej Fidei depositum, ogłoszonej z okazji publikacji Katechizmu Kościoła katolickiego, który ,,powinien raczej stać się zachętą i pomocą do opracowania katechizmów lokalnych, przystosowanych do różnorakich środowisk i kultur, a jednocześnie dbających o zachowanie jedności wiary oraz o wierność nauce katolickiej" (Jan Paweł II b.r.).

${ }^{4} \mathrm{~W}$ dalszym tekście używa się tytułu skróconego: Kompendium.

${ }^{5}$ Nie istnieje w polskiej literaturze przedmiotu opracowanie językoznawcze, porównujące język obu tych dzieł.

${ }^{6} \mathrm{~W}$ dalszym tekście używa się skróconego tytułu: YOUCAT. 
społeczności w ich języku i poruszyć ich problemy" (YOUCAT: 9). Celem deklarowanym przez twórców jest próba przekładu Katechizmu Kościoła katolickiego na język ludzi młodych pochodzących z różnych kontynentów i reprezentujących różne kultury. Katechizmowi YOUCAT, podobnie jak Kompendium, nadano formę dialogową, ujmując całość w 527 par pytanie - odpowiedź (Kompendium liczy 598 par $)^{7}$.

Przedmiotem mojego opracowania czynię analizę inicjalnej części każdego z bloków: pytań obecnych w polskim wydaniu katechizmu dla młodzieży. Obejmie ona 3 aspekty pozwalające na stworzenie charakterystyki tego elementu struktury YOUCAT:

1. status pytań katechizmowych,

2. kształt pytań (ujęcie jakościowe, nie zaś ilościowe),

3. osobliwości języka pytań.

\section{Status pytań katechizmowych}

Parzysty układ: pytanie - odpowiedź w genologii literackiej jest traktowany jako istotna cecha gatunku zwanego katechizmem. Mówi o tym np. Słownik terminów literackich ${ }^{8}$. Metoda zestawiania zapytań i odpowiedzi wywodzi się z antycznej tradycji dydaktycznej - dialogu mistrza i ucznia, ma również uzasadnienie mnemotechniczne: opanowanie pamięciowe utrwalonego kształtu odpowiedzi powiązanych z pytaniami o ustalonej formie pozwala na wierne odtworzenie stosunkowo obszernego zasobu treści, nie gwarantuje wszakże ich zrozumienia. $\mathrm{W}$ terminologii pragmalingwistycznej blok pytanie - odpowiedź nosi miano pary przylegającej (Awdiejew 1991: 7). Powrót do układu bloków rozpoczynanych pytaniami, widoczny tak w Kompendium, jak i w YOUCAT, może być traktowany jako ułatwienie co do segmentacji tekstu - zwalniając czytelnika z samodzielnego analizowania obszernych wywodów Katechizmu Kościoła katolickiego, twórcy parzystych segmentów wyodrębniają najistotniejsze kwestie, redukując w pewnej mierze elementy niekonieczne, np. uzasadnienia oraz opisy rozwoju myśli teologicznej na dany temat. W ten sposób koncentrują uwagę odbiorcy na wybranych zagadnieniach, podporządkowując je możliwie prostym pytaniom. Ułatwiają one poruszanie się po tekście, organizują zatem lekturę, nadają jej pewien kierunek, mogą pomagać w ewentualnym zapamiętywaniu.

Odrębnym problemem pozostaje językowy status pytań katechizmowych. Definicja zdania pytajnego, zapisana w Stowniku terminologii językoznawczej, odwołuje się do postawy mówiącego, który „szuka [...] potwierdzenia lub zaprzeczenia treści swego powiadomienia lub też uzupełnienia tej treści brakującym elementem" (Gołąb, Heinz, Polański 1968: 476). W teorii aktów mowy, sformułowanej przez Johna R. Searle’a, znajduje się m.in. sekwencja założeń,

\footnotetext{
${ }^{7}$ Por. opracowania dotyczące języka YOUCAT: Czarnecka 2012; Czarnecka 2013.

${ }^{8}$ Zob. hasło: Katechizm (Głowiński 1988: 217).
} 
dotyczących pytań i ich skuteczności. Obejmuje ona następujące warunki: „1. Nadawca nie może znać odpowiedzi, 2. Nadawca zakłada, że odbiorca zna odpowiedź, 3. Nadawca chce znać odpowiedź, 4. Nadawca żąda odpowiedzi od odbiorcy" (Wiertlewski 1995: 23; zob. też Searle 1987: 87-88). Jak pisze Monika Grzelka, „Warunek (1) jest warunkiem koniecznym, aby wypowiedzenie uznać za pytanie" (2008: 45). Podobnie przedstawia się ujęcie składniowe - w swym podręczniku Stanisław Jodłowski wiąże pytania z sytuacją, ,gdy mówiący nie zna interesującego go stanu rzeczy i domaga się udzielenia mu wyjaśniającej odpowiedzi” (1976: 58)9. Stefan Wiertlewski zaznacza jednak: ,postulaty zawarte w «klasycznym» ujęciu teorii aktów mowy nie obejmują wszystkich zjawisk związanych z użyciem języka" (1995: 24). Pytania i odpowiedzi katechizmowe są wyłącznie rodzajem narzędzia dydaktycznego - nadawcą tak pytania, jak i odpowiedzi jest ten sam twórca, nie ma zatem mowy o braku wiedzy u pytającego. Co więcej, kolejność wydawania interesujących nas katechizmów świadczy o tym, iż pytania zostały dopisane do treści, które dają początek odpowiedziom. Katechizmowe zdania pytające pozostają $\mathrm{w}$ zgodzie $\mathrm{z}$ jedną $\mathrm{z}$ reguł tworzenia pytań każde takie zdanie „uchodzi za próbę wydobycia informacji od słuchającego"10. Pytania katechizmu nie mogą być uznane za pytania rzeczywiste, przypominają one natomiast w pewnym stopniu tzw. pytania egzaminacyjne (dydaktyczne), w których pytający zna odpowiedź, lecz chce się dowiedzieć, czy zna ją i pytany (zob. Biłos 1994). Z punktu widzenia pragmatyki językowej pytania katechizmów są pytaniami pozornymi, naśladują jedynie rzeczywistą relację między nadawcą a odbiorcą. Bloki pytań i gotowych odpowiedzi, zapisane w publikacji drukowanej, elektronicznej itp., będące wyłącznie naśladownictwem dialogu - to metoda podawcza wybierana ze względów metodycznych, popularyzatorskich i mnemotechnicznych.

\section{Typologia pytań}

W zapisie pytania z katechizmu YOUCAT, podobnie jak i w Kompendium, na końcu wypowiedzenia pojawia się zawsze znak zapytania, odpowiadający charakterystycznej intonacji pytajnej ${ }^{11}$. Autorzy odrzucili możliwość posłużenia się zdaniem oznajmującym w funkcji pytania - mimo iż takie formy występują często tak w dialogu potocznym, jak i np. w wywiadzie dziennikarskim. Pod względem strukturalnym w katechizmie dla młodzieży dominują pytania rozpoczynające się

${ }^{9} \mathrm{Na}$ intencje nadawcy zwraca uwagę również Krystyna Pisarkowa - autorka hasła Zdanie pytające w Encyklopedii wiedzy o języku polskim (1978: 400-401).

${ }^{10}$ Monika Grzelka regułę tę nazywa regułą istotną (2008: 44).

${ }^{11}$ „Pytanie - log. Wypowiedź, za pomocą której mówiący domaga się udzielenia odpowiedniej informacji, zwykle identyfikowana na podstawie charakterystycznej intonacji, partykuł: czy, który, jak, gdzie itd., a w języku pisanym dodatkowo przez użycie określonego znaku graficznego - znaku zapytania" (Szymanek 2001: 260). 
od wyrazu lub wyrażenia pytajnego ${ }^{12}$ - partykuły (czy?), zaimka pytajnego (dlaczego?, jak?, kiedy?), wyrażenia o funkcji pytajnej (w jaki sposób?). Pojedyncze przykłady wypowiedzeń pozbawionych takiego członu inicjalnego są częścią szeregu, w którym pojawia się pytanie inicjowane zaimkiem, jak np. we fragmencie naśladującym zdumienie rozmówcy: „Grzech pierworodny? Co mamy wspólnego z upadkiem Adama i Ewy?" - pytanie 68 (YOUCAT: 50). Ze względu na stopień skomplikowania struktury składniowej przeważają zdania pojedyncze, także nierozwinięte: „Dlaczego pragniemy szczęścia?” - pytanie 281 (YOUCAT: 164), „Czy dozwolona jest eutanazja?” - pytanie 382 (YOUCAT: 209). Zdania złożone prawie zawsze oparte są na relacji podrzędnej: „Co dzieje się z nami, kiedy umieramy?” - pytanie 154 (YOUCAT: 94), ,Jak Chrystus pomaga nam przy umieraniu, kiedy Mu ufamy?" - pytanie 155 (YOUCAT: 94). Mimo dążenia do uproszczeń, które mogłoby przejawiać się także w składni, w analizowanym katechizmie zdarzają się konstrukcje wielokrotnie złożone, obejmujące kilkanaście wyrazów graficznych: „Czy istnieją grzechy, które są tak ciężkie, że nie może z nich rozgrzeszyć zwykły kapłan?” - pytanie 237 (YOUCAT: 138), „Jakie są zasadnicze wymogi, które musi spełnić chrześcijanin, żeby w sakramencie pokuty nastąpiło przebaczenie grzechów?" - pytanie 231 (YOUCAT: 136). Nieliczne zdania współrzędne przyjmują $\mathrm{w}$ zasadzie postać serii pytań przedstawionych jako jedno wypowiedzenie (z jednym znakiem zapytania), np. „Czy biskupi mogą postępować i nauczać wbrew papieżowi, czy papież może postępować wbrew biskupom?" pytanie 142 (YOUCAT: 88).

Zgodnie z typologią pytań, przywoływaną m.in. przez Stephena C. Levinsona w rozważaniu nt. presupozycji (2010: 214), w katechizmie dla młodzieży wyodrębnić można trzy podstawowe typy pytań: 1 . Pytania o rozstrzygnięcie, 2. Pytania alternatywne ${ }^{13}, 3$. Pytania o uzupełnienie. Cele katechizmu nie pozwalają natomiast na zamieszczenie w nim pytań retorycznych, z założenia pozbawionych odpowiedzi, nie ma także pytań wprost dopingujących odbiorcę do aktywności (stymulatywnych) (Wąsik 1979: 22).

Pytania o rozstrzygnięcie należą do grupy pytań zamkniętych, dopuszczają trzy potencjalne odpowiedzi: tak, nie, ewentualnie: nie wiem. W YOUCAT inicjuje je bezwyjątkowo partykuła $c z y$. Ich celem jest wydobycie stosunkowo prostej informacji, np. „Czy Kościół może się mylić w sprawach wiary?” - pytanie 13 (YOUCAT: 20), „Czy Pismo Święte jest prawdziwe?” - pytanie 14 (YOUCAT: 20), „Czy świat jest produktem przypadku?” - pytanie 43 (YOUCAT: 36), „Czy

${ }^{12}$ Izolowane przykłady pytań nie rozpoczynanych od zaimka zredagowane są w przestawionym szyku: „Wiara - co to jest?” - pytanie 21 (YOUCAT: 25); „Wierzyć - jak to jest?” - pytanie 22 (YOUCAT: 26). Ze względu na tradycję edytorską wymagającą przy cytowaniu katechizmów podawania numeru (paragrafu) po numerze strony w YOUCAT oraz w Kompendium pojawia się numer pytania (będący równocześnie numerem towarzyszącej mu odpowiedzi).

${ }^{13} \mathrm{Z}$ punktu widzenia logicznej teorii pytań pytania alternatywne są szczególnym przypadkiem pytań o rozstrzygnięcie - oba typy zaś należą do zbioru pytań zamkniętych (zob. Szymanek 2001: 261; Pisarkowa 1978). 
można kontaktować się z aniołami?" - pytanie 55 (YOUCAT: 43). Szczególnym przypadkiem jest seria pytań o rozstrzygnięcie, dająca niezbyt fortunny efekt tautologii: „Czy Bóg może wszystko? Czy jest wszechmogący?” - pytanie 40 (YOUCAT: 36). Co ciekawe, pytania o rozstrzygnięcie, bardzo licznie reprezentowane na stronicach $Y O U C A T^{14}$, nie zawsze pociągają za sobą proste odpowiedzi, rozpoczynające się od potwierdzenia lub zaprzeczenia. W Kompendium trudniej jest znaleźć pytania o rozstrzygnięcie; spośród nielicznych przykładów warto przywołać np. punkty dotyczące kultu obrazów („Czy nakaz Boży: «nie będziesz czynił żadnej rzeźby...» (Wj 20,3) zakazuje kultu obrazów?” - pytanie 446 (Kompendium: 148) lub problemów współczesnej bioetyki („Czy dozwolone są przeszczepy i oddawanie narządów przed śmiercią lub po śmierci?” - pytanie 476 (Kompendium: 156)).

Pytania alternatywne, również zamknięte, niezbyt częste w YOUCAT, przedstawiają dwa rozwiązania o tej samej wadze, zapraszają do dokonania wyboru spośród możliwości wskazanych w samym pytaniu, np. „Czy w Jezusie Chrystusie wszystko zostało już powiedziane, czy też po nim Objawienie nadal będzie trwało?” - pytanie 10 (YOUCAT: 18), „Wierzymy w jednego Boga czy w trzech bogów?" - pytanie 35 (YOUCAT: 32). Pytań takich nie wprowadzono do Kompendium.

Najbogatszą grupę w obu publikacjach tworzą pytania o uzupełnienie, zaliczane do kategorii pytań otwartych, dopuszczające dużą dowolność odpowiedzi. Ze względu na podobieństwo formalne przykłady ograniczam do materiału zaczerpniętego z YOUCAT. Są wśród nich przede wszystkim bardzo liczne pytania o cel: „Po co jesteśmy na ziemi?” - pytanie 1 (YOUCAT: 14), „Po co Jezus powołał apostołów?” - pytanie 61 (YOUCAT: 92), sposób: „Jak poprawnie czytać Biblię?” - pytanie 16 (YOUCAT: 21), „Jak możemy odpowiedzieć Bogu, gdy się do nas zwraca?" - pytanie 20 (YOUCAT: 25), ,Jak powstały wyznania wiary?” - pytanie 27 (YOUCAT: 28) i o uzasadnienie: „Dlaczego Bóg nas stworzył?” - pytanie 2 (YOUCAT: 14), „Dlaczego szukamy Boga?” - pytanie 3 (YOUCAT: 14), „Czemu Jezus przemienił się na górze?” - pytanie 93 (YOUCAT: 61). Uwagę zwraca odejście od wzorcowej, oficjalnej polszczyzny - popularność kolokwialnej formy cze$m u$ rywalizującej ze staranniejszym dlaczego, a także rezygnacja $\mathrm{z}$ oficjalnego w jakim celu na rzecz prostszego po co. Mniejszą frekwencję (w poszczególnych podgrupach) mają zróżnicowane pytania o uzupełnienie, dotyczące np. znaczenia bądź roli, czasu, ilości, treści tekstu, kompetencji osób, źródła informacji, przebiegu wydarzeń itp.: „Jakie znaczenie ma dla chrześcijan Stary Testament?” pytanie 17 (YOUCAT: 23), „Jaką rolę w życiu Jezusa odgrywa Duch Święty?” pytanie 114 (YOUCAT: 73), „Kiedy Chrystus ustanowił Eucharystię?” - pytanie 209 (YOUCAT: 124), „Skąd wiemy, co stanowi prawdziwą wiarę?” - pytanie 12 (YOUCAT: 19), „Co wydarzyło się podczas Pięćdziesiątnicy?” - pytanie 118 (YOUCAT: 75), „Komu wolno bierzmować?” - pytanie 207 (YOUCAT: 123).

${ }^{14} \mathrm{~W}$ YOUCAT znajdują się aż 92 pytania o rozstrzygnięcie, rozpoczynające się od partykuły „czy” (dla porównania - w Kompendium są tylko 24). 
Ze względu na popularyzatorskie założenia katechizmu dla młodzieży szczególne miejsce wśród pytań uzupełniających ${ }^{15}$ zajmują pytania o wyjaśnienie pojęcia, a tym samym o jego zdefiniowanie. Rozpoczynają się one od członu: co to jest? (w liczbie mnogiej co to sa?) lub kto to jest?, np. „Co to jest niebo?” - pytanie 52 (YOUCAT: 42), „Co to jest sumienie?” - pytanie 295 (YOUCAT: 171), „Kto to jest Duch Święty?" - pytanie 38 (YOUCAT: 35). Wyróżniają się prostą, schematyczną budową i ograniczeniem liczby słów ${ }^{16}$. Należy podkreślić, że odpowiedzi na pytania o definicję nie są jedynym źródłem wiedzy na temat wybranych pojęć - na marginesach katechizmu pojawia się bowiem ponad 100 krótkich artykułów o charakterze definicji encyklopedycznej, tłumaczących takie pojęcia, jak np. bluźnierstwo, blogostawieństwo, cnota, celibat (Czarnecka 2012).

Sposobem realizacji programowego zamiaru sporządzenia przekładu Katechizmu Kościoła katolickiego na język młodzieży jest wprowadzenie bloków dotyczących znaczenia wyrazów i połączeń wyrazowych - pytania dotyczą przede wszystkim wyspecjalizowanego słownictwa religijnego (teologicznego), frazeologii biblijnej, a także całych formuł wyrażających prawdy wiary oraz tekstów modlitewnych. Pytanie te otwiera człon: co to znaczy? // co oznacza?, np. „Co to znaczy, że człowiek został stworzony na «obraz Boży»?" - pytanie 58 (YOUCAT: 45), „Co to znaczy: wierzę w Ducha Świętego?” - pytanie 11 (YOUCAT: 18). Niektóre wyrażenia charakterystyczne dla języka religijnego zostały podkreślone poprzez ujęcie w cudzysłów, np. „Czemu my także musimy akceptować cierpienie w naszym życiu, «brać krzyż na swoje ramiona» i w ten sposób naśladować Jezusa?" - pytanie 102 (YOUCAT: 67), redaktorzy nie są jednak w tej kwestii konsekwentni. Istotna różnica wobec Kompendium polega na niestosowaniu w YOUCAT pytań rozpoczynających się od wyrażenia $w$ jakim sensie...? (przykłady z Kompendium: „W jakim sensie całe życie Chrystusa jest misterium?”pytanie 101 (Kompendium: 48), „W jakim sensie Kościół jest ciałem Chrystusa?” - pytanie 156 (Kompendium: 62)).

Zestawienie kompletu pytań z YOUCAT dowodzi powtarzalności modeli. Autorzy wybierają schematyczne rozwiązania, nie szukają oryginalności, dążą do uproszczeń. Zdarza się, że pytania zamieszczone w bezpośrednim sąsiedztwie układają się w bliźniacze zestawy, dwu- lub trójelementowe, jak w serii: „Co to znaczy, że Kościół jest...” - kolejno: „...Ciałem Chrystusa?” - pytanie 126 (YOUCAT: 80), „...Oblubienicą Chrystusa?” - pytanie 127 (YOUCAT: 80), „...«Świątynią Ducha Świętego»?” - pytanie 128 (YOUCAT: 80).

15 Tak pytania o uzupełnienie nazywa K. Pisarkowa (1978: 400).

16 Pytania realizujące modele: co to jest, co to sa, a także: co znaczy, co oznacza można odnaleźć również na stronicach Kompendium, np. „Co to jest pokuta wewnętrzna?” - pytanie 300 (Kompendium: 103), „Co oznacza przeistoczenie?”- pytanie 382 (Kompendium: 100). 


\section{Osobliwości pytań katechizmowych}

Lektura YOUCAT skłania do opisu kilku charakterystycznych zjawisk mających wpływ na obraz katechizmowych pytań.

Pierwszym z nich jest obecność treści presuponowanych, niewyrażanych wprost, lecz wynikających z kształtu pytania i poprzedzających je. Z pytania „Dlaczego błogosławieństwa są tak ważne?” - pytanie 284 (YOUCAT: 165) wynika wstępne założenie o ważności błogosławieństw; pytanie „Co jest wyjątkowe w ludzie Bożym?" - pytanie 125 (YOUCAT: 79) sugeruje, że coś wyjątkowego istnieje. W katechizmie pojawiają się również pytania, dla których punktem wyjścia jest niedowierzanie czy wątpliwość co do wcześniej poznawanego stanu rzeczy (pojawia się tu pokrewieństwo do pytań dubitatywnych). Wyrazem takiej niepewności jest obecność przysłówka rzeczywiście, np. „Czy papież rzeczywiście jest nieomylny?” - pytanie 143 (YOUCAT: 89), „Czy Maryja może nam rzeczywiście pomóc?" - pytanie 148 (YOUCAT: 92). Przykłady te dowodzą, że pytania w YOUCAT nie są pozbawione waloru perswazyjnego. Tak skonstruowanych pytań nie ma natomiast w Kompendium.

Drugie ze spostrzeżeń dotyczy niejednorodnego ukształtowania relacji nadawczo-odbiorczych. Redaktorzy YOUCAT chętnie posługują się perspektywą pierwszoosobową, zwłaszcza w liczbie mnogiej - my inkluzywne, ujawniające się w formach czasownikowych i zaimkowych, kreuje wspólnotę, w której nie ma podziału na pouczających i pouczanych, np. „Dlaczego wierzymy w zmartwychwstanie umarłych?” - pytanie 152 (YOUCAT: 93), ,Jak powinniśmy się obchodzić z naszym ciałem?" - pytanie 387 (YOUCAT: 212). Przeznaczenie katechizmu, adresowanego do młodych ludzi na całym świecie, pozwala na przyjęcie także innej interpretacji - formy my jednoczacego, „które obejmuje nadawcę odbiorcę i kogoś jeszcze: osobę trzecią lub jej wielokrotność" (Łysakowski 2005: 40). W pojedynczych przypadkach zastosowano 1 . osobę liczby pojedynczej (,Jak powinienem przygotować się do spowiedzi?" - pytanie 232 (YOUCAT: 136)). Pytania takie sąsiadują z wypowiedzeniami o konstrukcji trzecioosobowej, typu: ,Jak chrześcijanie uzasadniają ludzką godność?" - pytanie 280 (YOUCAT: 162) - oraz z zapytaniami skoncentrowanymi wokół form niefleksyjnych typu wolno, należy, trzeba. Brak przy tym jakichkolwiek jasnych przesłanek, którymi można byłoby uzasadnić wybór któregoś z omówionych rozwiązań. Zauważalne jest natomiast konsekwentne unikanie form drugoosobowych, które - tak w znaczeniu inkluzywnym (bezpośredni odbiorca i osoby trzecie), jak i ekskluzywnym (odbiorca bez osób trzecich) mogłyby wywoływać wrażenie dystansu dzielącego nadawcę od odbiorców. Dodajmy, że we wcześniejszym Kompendium preferowano neutralne formy nieokreślające osoby, mimo możliwości innej redakcji pytań ${ }^{17}$. Auto-

17 Pytania: „Jakie grzechy należy wyznać?” - pytanie 304 (Kompendium: 104), „Czy jest możliwe zachowanie Dekalogu?” - pytanie 441 (Kompendium: 147) mogłyby przybrać np. postać: *jakie grzechy powinien wyznawać chrześcijanin? i *czy chrześcijanin jest zdolny do zachowania Dekalogu? 
rzy Kompendium posługują się jednak, choć niezbyt często, 1. osobą liczby mnogiej („Kiedy jesteśmy zobowiązani wyznać grzechy ciężkie?” - pytanie 305 (Kompendium: 104), „Dlaczego możemy wzywać Boga jako «Ojca»?” - pytanie 583 (Kompendium: 190)).

Kwestia trzecia dotyczy kształtu stylistycznego pytań w katechizmie dla młodzieży, a przede wszystkim - doboru słownictwa. Tematyka opracowania narzuca tu konieczność posłużenia się leksyką religijną. Redaktorzy zdają sobie jednak sprawę z pewnej hieratyczności i sterminologizowania tekstów tradycyjnych; pytając o przynajmniej niektóre wyrazy i ich połączenia, sfrazeologizowane w piśmiennictwie religijnym, starają się szukać ich znaczenia - a w odpowiedzi umieszczać wyjaśnienie. Słownictwo specjalistyczne ulega wyraźnemu ograniczeniu. W zamian pojawiają się pojedyncze sygnały potoczności, widoczne w słownictwie i składni takich pytań, jak np. „Co z osobami homoseksualnymi?” - pytanie 65 (YOUCAT: 48) (pytanie z elipsą), „Co to będzie, kiedy nastąpi koniec świata?” - pytanie 111 (YOUCAT: 72), „Jak człowiek wpada na to, by się modlić?" - pytanie 470 (YOUCAT: 258). Wyraźną próbą zbliżenia do zwyczajów potocznego dialogu jest wspomniane już zastąpienie pytania dlaczego mniej oficjalnym czemu. Niektóre potocyzmy zaznaczono cudzysłowami, co można interpretować jako wyraz dystansu do form użytych na prawach stylizacji, np. „Czy rozwód jest «w porządku»?” - pytanie 424 (YOUCAT: 231), „Czemu Kościół jest przeciwny małżeństwu «bez papierka»?" - pytanie 425 (YOUCAT: 231). Sformułowania te pozostają $\mathrm{w}$ kontraście wobec znacznie mniej przystępnych zdań, w których nie zrezygnowano ze słownictwa naukowego, typu: „W jaki sposób Eucharystia jest antycypacją życia wiecznego?" - pytanie 223 (YOUCAT: 133). Pytania w YOUCAT cechują się zatem stylistyczną niejednorodnością, której uniknięto w Kompendium, zachowującym oficjalny język pisany.

\section{Podsumowanie}

Pytania konstytuujące postać dialogową katechizmu YOUCAT są formą wtórną wobec treści katechizmowych. Należy je traktować jako środek dydaktyczny, ułatwiający lekturę tekstu, poruszanie się po nim i opanowanie przedstawianego materiału. Tę samą, służebną funkcję pełnią pytania we wcześniejszym Kompendium. Zachowując pewną ostrożność, można założyć, że pytania są również nośnikami sugestii co do tego, co zdaniem twórców katechizmu powinno przykuwać uwagę czytelnika - podpowiadają, o co należy pytać, tak w kwestiach doktrynalnych, jak i praktycznych, jeśli pragnie się życia w pełni chrześcijańskiego. W katechizmie dla młodzieży istotną rolę odgrywają pytania o rozstrzygnięcie, rzadsze w Kompendium, jak również nieobecne tam pytania alternatywne. W obu opracowaniach dominują pytania o uzupełnienie. YOUCAT różni się od poprzednika wielością pytań o definicję (mniej liczne w Kompendium) oraz tych, których celem jest wyjaśnienie utrwalonych $\mathrm{w}$ języku religijnym wyrazów i połączeń wyra- 
zowych. Specyfika tego katechizmu ujawnia się też w próbie budowania więzi między nadawcą a wirtualnym odbiorcą, wyrażającej się skłonnością do używania w pytaniach form 1 . osoby liczby mnogiej. Redaktorzy obu publikacji starali się tworzyć pytania możliwie proste, co skutkuje powtarzalnością schematów. Korpus pytań YOUCAT nie jest jednorodny pod względem stylistycznym, zawiera tak spetryfikowane słownictwo religijne, jak i pewne elementy leksyki z kręgu mowy potocznej. Również i ta cecha odróżnia tekst YOUCAT od Kompendium, bardziej oficjalnego, pozbawionego jakichkolwiek sygnałów potoczności.

\section{ŹRóDeA}

Kompendium - Kompendium Katechizmu Kościoła katolickiego, Kielce 2005. YOUCAT - YOUCAT polski. Katechizm Kościoła katolickiego dla młodych, Częstochowa 2011.

\section{Bibliografia}

Awdiejew A., 1991, Strategie konwersacyjne (Próba typologii), „Socjolingwistyka” 11, s. 7-20.

Bajerowa I., 1999, O stownictwie nowego katechizmu, w: Tysiac lat polskiego stownictwa religijnego, red. B. Kreja, Gdańsk, s. 253-263.

Bajerowa I., 2008, Od Trydentu do Vaticanum Secundum. Porównanie języka dwóch katechizmów, w: Język katechezy, red. R. Przybylska, W. Przyczyna, Tarnów, s. 136-151, [pierwodruk w: Od Biblii Wujka do wspótczesnego języka religijnego, red. Z. Adamek, S. Koziara, Tarnów 1999].

Biłos E., 1994, Sens pytań dydaktycznych. Przykład rozważań nad komunikacją ćwiczenia językowego, Częstochowa.

Bugajski M., 2008, Uwagi o komunikatywności i zrozumiałości słownictwa Katechizmu Kościoła katolickiego, w: Język katechezy, red. R. Przybylska, W. Przyczyna, Tarnów, s. $152-162$.

Czarnecka K., 2012, Uwagi o kształcie definicji w katechizmie dla młodzieży ,,YOUCAT”, w: W kręgu języka tożsamości. Język - religia-tożsamość VII, red. G. Cyran, E. Skorupska-Raczyńska, Gorzów Wielkopolski, s. 43-56.

Czarnecka K., 2013, Odpowiedzi katechizmowe jako sposób popularyzacji nauczania Kościoła. Uwagi o języku katechizmu „,YOUCAT”, „Poznańskie Zeszyty Humanistyczne", s. 103-118.

Głowiński M., 1988, Katechizm [hasło], w: Słownik terminów literackich, red. M. Głowiński, T. Kostkiewiczowa, A. Okopień-Sławińska, J. Sławiński, Wrocław, s. 217.

Gołąb Z., Heinz A., Polański K., 1968, Stownik terminologii językoznawczej, Warszawa. Grzelka M., 2008, Pytanie dziennikarskie. Pragmatyka i retoryka, Poznań.

Jan Paweł II, b.r., Konstytucja Apostolska Fidei depositum ogloszona z okazji publikacji „Katechizmu Kościoła katolickiego” opracowanego po Soborze Powszechnym Watykańskim II, http://www.katechizm.opoka.org.pl/rkkkap.htm [dostęp: 24.02.2018].

Levinson S.C., 2010, Pragmatyka, Warszawa.

Łysakowski T., 2005, Wplywowe osoby. Gramatyka i perswazja, Warszawa. 
Pisarkowa K., 1978, Zdanie pytające [hasło], w: Encyklopedia wiedzy o języku polskim, red. S. Urbańczyk, Wrocław, s. 400-401.

Rybka M., Sławek J., 2008, O ewolucji funkcji komunikatywnej. Na podstawie porównania katechizmów z wieku XIX i współczesnego, w: Język katechezy, red. R. Przybylska, W. Przyczyna, Tarnów, s. 163-178.

Searle J.R., 1987, Czynności mowy. Rozważania z filozofii języka, Warszawa.

Szymanek K., 2001, Pytanie [hasło], w: Sztuka argumentacji. Słownik terminologiczny, Warszawa, s. 260.

Wąsik Z., 1979, Typologia wypowiedzeń pytajnych, Wrocław.

Wiertlewski S., 1995, Pytania bez odpowiedzi, Poznań.

YOUCAT, 2011, Jugendkatechismus der Katholischen Kirche, Muenchen. 
